\title{
The Production of UV Absorber Amorphous Cerium Sulfide Thin Film
}

\author{
Ishak Afşin Karipera * \\ ${ }^{a}$ Faculty of Education, Erciyes University, 38039, Kayseri, Turkey
}

Received: December 05, 2016; Revised: April 29, 2017; Accepted: July 03, 2017

\begin{abstract}
This study investigates the production of cerium sulfide $\left(\mathrm{CeS}_{\mathrm{x}}\right)$ amorphous thin films on substrates (commercial glass) by chemical bath deposition at different $\mathrm{pH}$ levels. The transmittance, absorption, optical band gap and refractive index of the films are measured by UV/VIS Spectrum. According to $\mathrm{XRD}$ analysis, the films show amorphous structure in the baths with $\mathrm{pH}: 1$ to 5 . It has been observed that the optical and structural properties of the films depend on $\mathrm{pH}$ value of the bath. The optical band gap $(2.08 \mathrm{eV}$ to $3.16 \mathrm{eV})$ of the films changes with the film thickness $(23 \mathrm{~nm}$ to $1144 \mathrm{~nm})$. We show that the refractive index has a positive relationship with the film thickness, where the values of 1.93, $1.45,1.42,2.60$ and 1.39 are obtained for the former, and 34, 560, 509, 23 and $1144 \mathrm{~nm}$ (at $550 \mathrm{~nm}$ wavelength) for the latter. We compare the optical properties of amorphous and crystal form of $\mathrm{CeS}_{\mathrm{x}}$ thin films. We show that the optical band gaps of the amorphous $\mathrm{CeS}_{\mathrm{x}}$ are lower than that of crystal $\mathrm{CeS}_{\mathrm{x}}$.
\end{abstract}

Keywords: $C e S_{x}$ thin films, Chemical Bath Deposition, Thin film, UV absorber glass

\section{Introduction}

As a lanthanide, cerium is strongly electropositive. It can easily transformed to oxides. The cerium salts such as hydroxide, carbonate, oxalate, phosphate, fluoride and sulfide are insoluble in the water. With the transitions between $4 \mathrm{f}$ and $5 \mathrm{~d}$ electron configurations, cerium (III) compounds can absorb light in ultraviolet region outside the visible area. Cerium has many sulfide compounds, such as cerium (III) sulfide, $\mathrm{Ce}_{2} \mathrm{~S}_{3}$, cerium mono sulfide, $\mathrm{CeS}$, and tri cerium tetra sulfide, $\mathrm{Ce}_{3} \mathrm{~S}_{4}{ }^{1-3}$.

Cerium (III) sulfides are known as sesquisulfides. Cerium sesquisulfides exist in three different allotropic forms as $\alpha-\mathrm{Ce}_{2} \mathrm{~S}_{3}, \beta-\mathrm{Ce}_{2} \mathrm{~S}_{3}$ and $\gamma-\mathrm{Ce}_{2} \mathrm{~S}_{3}$. The structure and colors of these sulfides are as follows: black/brown or orange in orthorhombic form, burgundy in tetragonal form and dark red in cubic form. According to the literature, $\alpha-\mathrm{Ce}_{2} \mathrm{~S}_{3}$, $\beta-\mathrm{Ce}_{2} \mathrm{~S}_{3}$ and $\gamma-\mathrm{Ce}_{2} \mathrm{~S}_{3}$ are formed at high temperature, that is $<900{ }^{\circ} \mathrm{C},>900{ }^{\circ} \mathrm{C}$ and $>1200{ }^{\circ} \mathrm{C}$, respectively. Cerium mono sulfides have also different thermal and electrical properties. Moreover, cerium oxides are used in a wide variety of technologic areas ${ }^{2-3}$.

This paper aims to produce $\mathrm{CeS}_{\mathrm{x}}$ thin films via chemical bath deposition, at different $\mathrm{pH}$ values, and to examine their structural and optical properties. With amorphous $\mathrm{CeS}_{\mathrm{x}}$ form, we can obtain thin films with lower optic band gap and reflection index. The optical properties of $\mathrm{CeS}_{\mathrm{x}}$ thin films can be controlled with the $\mathrm{pH}$ of the chemical bath. To our knowledge, there exists no study on the production of $\mathrm{CeS}_{\mathrm{x}}$ thin films via chemical bath deposition for solar cells, sensors or detectors. The relation between $\mathrm{pH}$ of the bath and the structural and the optical properties of $\mathrm{CeS}_{\mathrm{x}}$

\footnotetext{
* e-mail: akariper@gmail.com
}

film has not been studied so far, especially for the cerium sulfides films which are produced at the acidic area. Kariper ${ }^{4}$ has produced crystalline cerium sulfide thin films at the $\mathrm{pH}$ values greater than 6 . This study compares optical properties of crystalline and amorphous $\mathrm{CeS}_{\mathrm{x}}$ thin films.

\section{Experimental Method}

The components of bath are concentrated ammonia solution, $0.1 \mathrm{M}\left(\mathrm{NH}_{4}\right)_{2} \mathrm{Ce}\left(\mathrm{NO}_{3}\right)_{6}$ and $0.2 \mathrm{M}$ thioacetamide. First, $10 \mathrm{ml}$ $0.1 \mathrm{M}\left(\mathrm{NH}_{4}\right)_{2} \mathrm{Ce}\left(\mathrm{NO}_{3}\right)_{6}$ and $10 \mathrm{ml} 0.2 \mathrm{M}$ thioacetamide are added in baker containing $20 \mathrm{ml}$ deionized water. Concentrated ammonia solution is used to adjust the $\mathrm{pH}$ of the bath. $60 \mu \mathrm{l}$, $80 \mu \mathrm{l}, 120 \mu \mathrm{l}$ and $180 \mu \mathrm{l}$ of concentrated ammonia solution $\left(\mathrm{NH}_{3}\right)$ are added to the prepared baths to adjust their $\mathrm{pH}$ values to 2,3,4 and 5. The $\mathrm{pH}$ values of the chemical baths are measured using a pH meter (Lenko mark $6230 \mathrm{~N}$ ). The original $\mathrm{pH}$ of the solution is 1.15 before adding ammonia to the baker. Chemical baths are hold at $50^{\circ} \mathrm{C}$ for 12 hours.

The crystalline structure of $\mathrm{CeS}_{x}$ is confirmed by X-ray diffraction (XRD) with a $\mathrm{CuK} \alpha_{1}$ radiation source (Rikagu RadB model, $\lambda=1.5406 \AA$ ) over the range $10^{\circ}<2 \theta<90^{\circ}$ at a speed of $3^{\circ} \mathrm{min}^{-1}$ with a step size of $0.02^{\circ}$. Optical measurements are performed at room temperature using Hach Lange 500 Spectrophotometer, by placing an uncoated identical commercial glass substrate to the reference beam. Optical spectrum of thin films is recorded at the wavelength range of 300-1100 nm.

\section{Results and Discussion}

Fig. 1 shows XRD patterns of various cerium sulfide thin films produced at different $\mathrm{pH}$ values by using chemical bath 
deposition method (a: $\mathrm{pH}$ 1, b: $\mathrm{pH} 2$, c: $\mathrm{pH}$ 3, d: $\mathrm{pH}$ 4, e: $\mathrm{pH}$ 5). XRD patterns of the films show amorphous structure form for $\mathrm{CeS}_{\mathrm{x}}$. Kariper ${ }^{4}$ and Witz et al. ${ }^{5}$ have obtained crystalline structures for $\mathrm{CeS}_{\mathrm{x}}$ at $\mathrm{pH}>6$. They have also observed no relationship between thicknesses of the thin films and $\mathrm{pH}$ of the bath. In this study, film thicknesses are found to be 34, 560, 509, 23 and $1144 \mathrm{~nm}$ for $\mathrm{pH} 1,2,3,4$ and 5, respectively, as shown in Fig. 2.

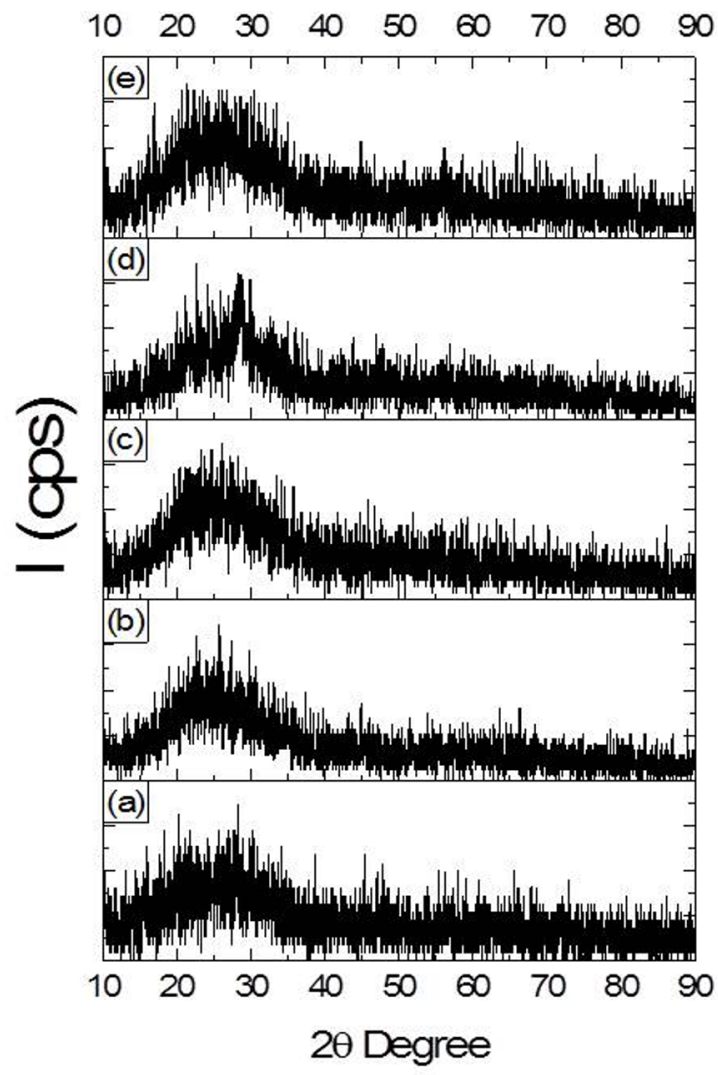

Figure 1. XRD spectrum of Cerium Sulfide thin films produced at different $\mathrm{pHs}$ (a) $\mathrm{pH}: 1$, (b) $\mathrm{pH}: 2$, (c) pH: 3, (d) $\mathrm{pH}: 4$, (e) $\mathrm{pH}: 5$.

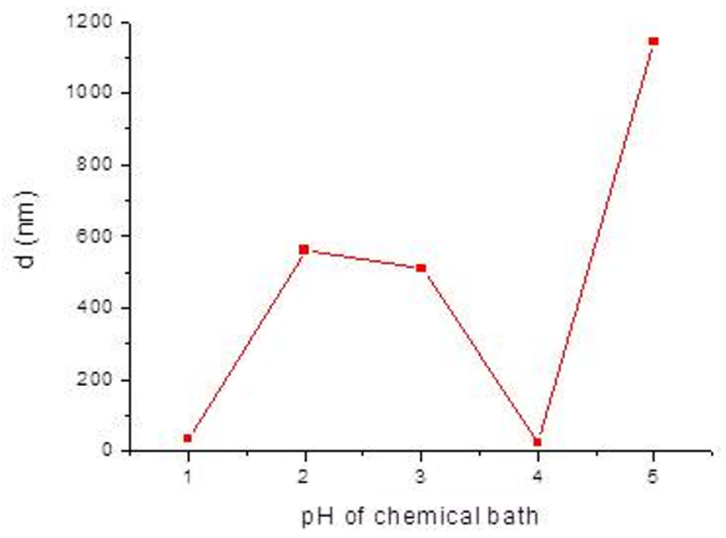

Figure 2. Film thickness of $\mathrm{CeS}_{\mathrm{x}}$ thin films produced at different $\mathrm{pH}$.
Optic band gap energy (Eg) is determined from the absorption spectra of the films using the following relation, where $\mathrm{A}$ is a constant, $\alpha$ is absorption coefficient, $\mathrm{h} v$ is the photon energy and $\mathrm{n}$ is a constant, equal to $1 / 2$ for direct band gap semiconductor.

$$
(\alpha h v)=(h v-E g)^{n}
$$

Figure 3 shows the plot of $(\alpha h v)^{2}$ vs. hv for $\mathrm{CeS}_{\mathrm{x}}$ films produced at different $\mathrm{pH}$ : (a) $\mathrm{pH}$ 1, (b) $\mathrm{pH} 2$, (c) $\mathrm{pH} 3$, (d) $\mathrm{pH} \mathrm{4,} \mathrm{(e)} \mathrm{pH} \mathrm{5.} \mathrm{Witz} \mathrm{et} \mathrm{al.} \mathrm{have} \mathrm{stated} \mathrm{that} \mathrm{direct} \mathrm{band} \mathrm{gap}$ of pure single crystal cerium sulfides thin film (especially, sesquisulfides) is higher than $3.3 \mathrm{eV}$, because its dielectric constant is high ${ }^{5}$. We have calculated optical band gap of crystalline cerium sulfide thin films in the range of 2.86-3.23 $\mathrm{eV}$. Urbach tail formed in amorphous structure allows the parabolic conductivity band to switch to a lower energy level, which is just below the conductivity band of the energy tail. Therefore, excited electrons are positioned at this energy level before switching to the conductivity band, which leads to an increase on conductivity. These results show that amorphous $\mathrm{CeS}_{\mathrm{x}}$ thin films are very useful for solar cells ${ }^{5}$.

Transmittance $(\mathrm{T})$ of $\mathrm{CeS}_{\mathrm{x}}$ thin film can be calculated by using reflectivity (R) and absorbance (A) spectra from the following expression:

$$
T=(1-R)^{2} e^{-A}
$$

Transmission measurements shown in figure 4 are performed at room temperature, in the range of 300-1100 $\mathrm{nm}$. Transmission is calculated as $68,88,89,45$ and $90 \%$ (at $550 \mathrm{~nm}$ wavelength), for film thickness 34, 560, 509, 23 and $1144 \mathrm{~nm}$, respectively. In addition, reflectance values have been calculated and found to be 10.13, 3.38, 3.07, 19.75 and $2.76 \%$ respectively (at $550 \mathrm{~nm}$ wavelength). According to literature, the reflectance of cerium sulfides is around $10 \%$ at $550 \mathrm{~nm}$ wavelength, however bulk cerium sulfides show higher reflectance over $700 \mathrm{~nm}$ wavelengths. It is known that reflectance is related to film thickness. Transmissions of the films are in line with film thicknesses. Cerium sulfides are known to be useful reflectors with high performance pigment ${ }^{2}$.

Refractive index and extinction coefficient of the films are computed by the following formulas:

$$
\begin{gathered}
n=\frac{(1+R)}{(1-R)}+\sqrt{\frac{4 R}{(1-R)^{2}}-k^{2}} \\
k=\frac{\alpha \lambda}{4 \Pi}
\end{gathered}
$$

Refractive index values of 1.93, 1.45, 1.42, 2.60 and 1.39 (at $550 \mathrm{~nm}$ wavelength), shown in figure 5, is in line with the film thickness, which is measured as 34, 560, 509, 23 

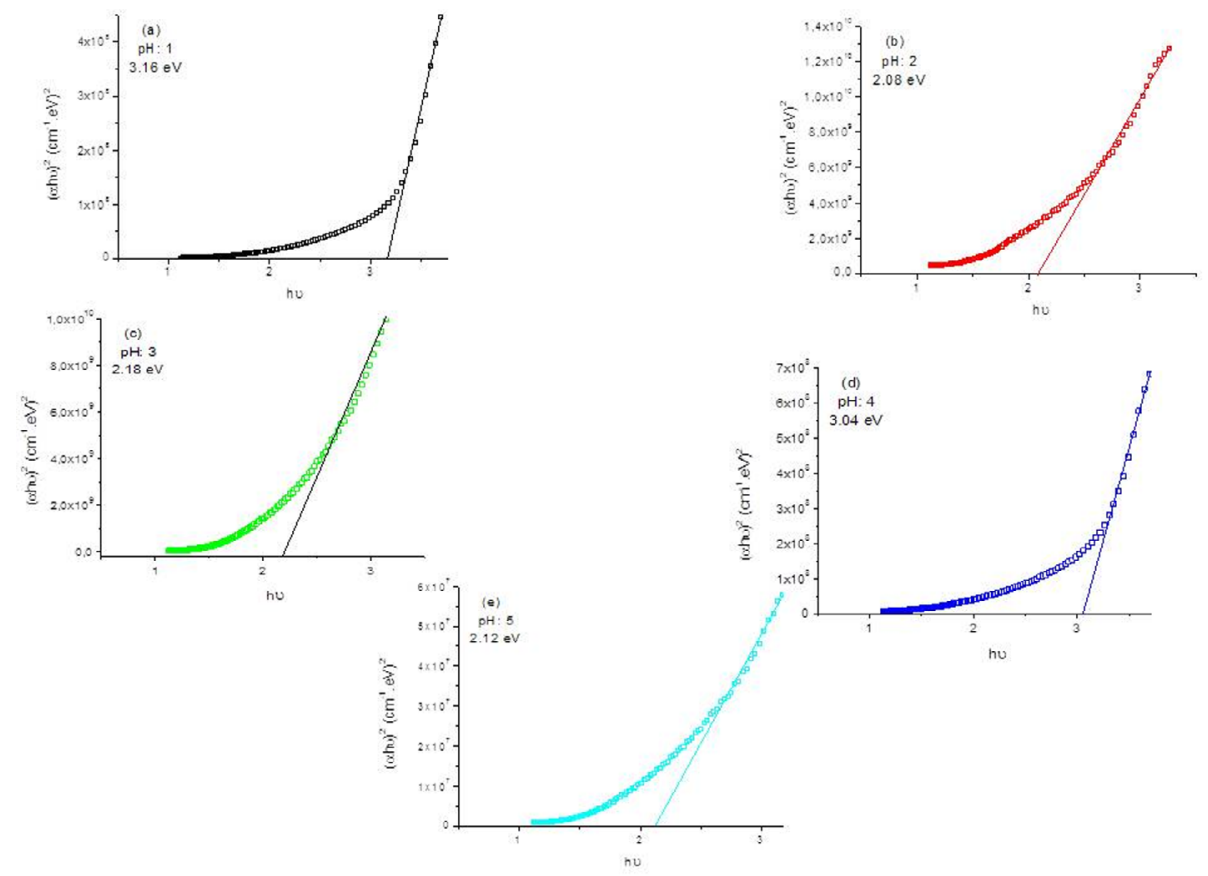

Figure 3. Plot of $(\alpha h v)^{2}$ vs. hv for $\mathrm{CeS}_{\mathrm{x}}$ films produced at different $\mathrm{pH}$ : (a) $\mathrm{pH}$ 1, (b) $\mathrm{pH}$ 2, (c) $\mathrm{pH} 3$, (d) $\mathrm{pH}$ 4, (e) $\mathrm{pH} 5$.
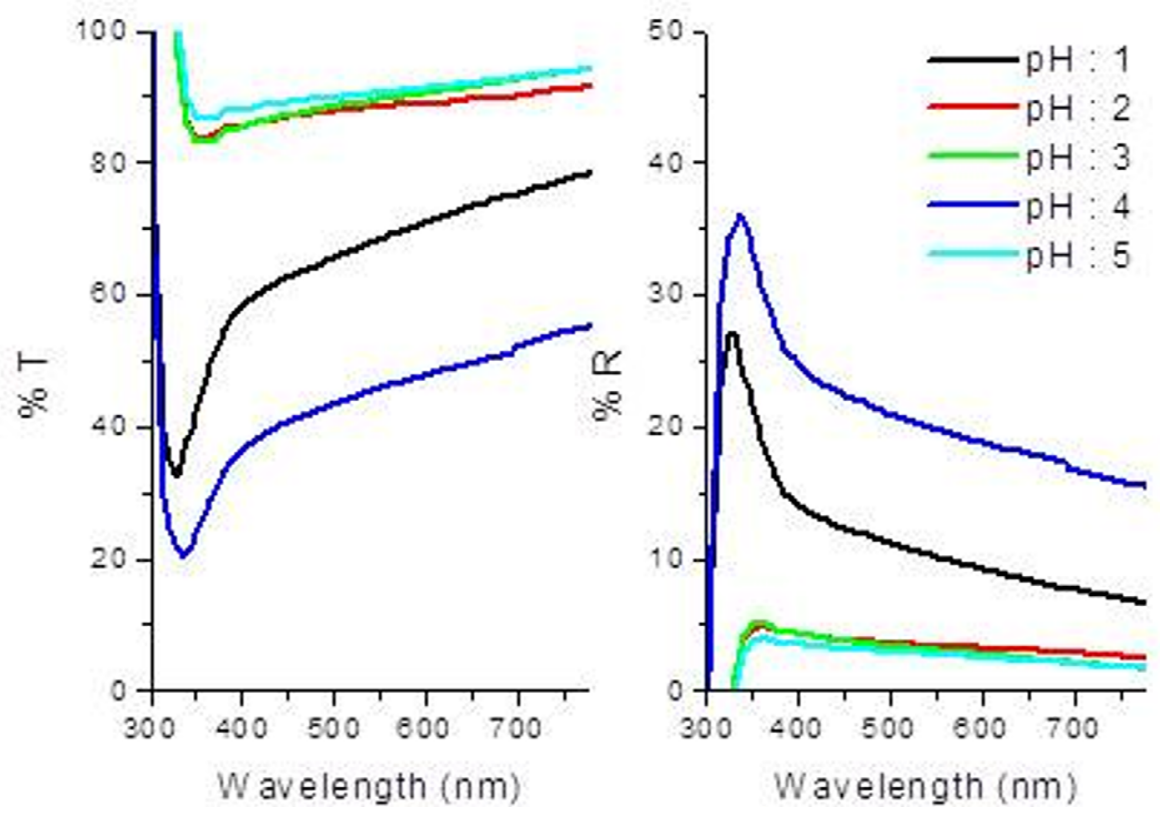

Figure 4. Transmittance $(\mathrm{T})$ and reflectivity $(\mathrm{R})$ of $\mathrm{CeS}_{\mathrm{x}}$ thin films produced at different $\mathrm{pH}$.

and $1144 \mathrm{~nm}$, respectively. Extinction coefficient, calculated as $0.011,0,003,0.003,0.024$ and 0.003 , is also behaved as refractive index (at $550 \mathrm{~nm}$ wavelength). Refractive index of cerium sulfides $\left(\mathrm{Ce}_{2} \mathrm{~S}_{3}\right)$ is known to be $2.7^{2}$. Refractive index of bulk cerium sulfides is around 2.5-3 in visible region, and 3-3.5 in UV region. Similarly, extinction coefficient of bulk cerium sulfides is around 0-0.5 in visible region, however it increases to 1.0 in UV region ${ }^{2,6}$. According to these results, thinner films that we have produced show better reflective properties than the thicker films in the literature. These results show that the optical properties of the films are in line with the film thicknesses. In the literature, UV absorbing materials 

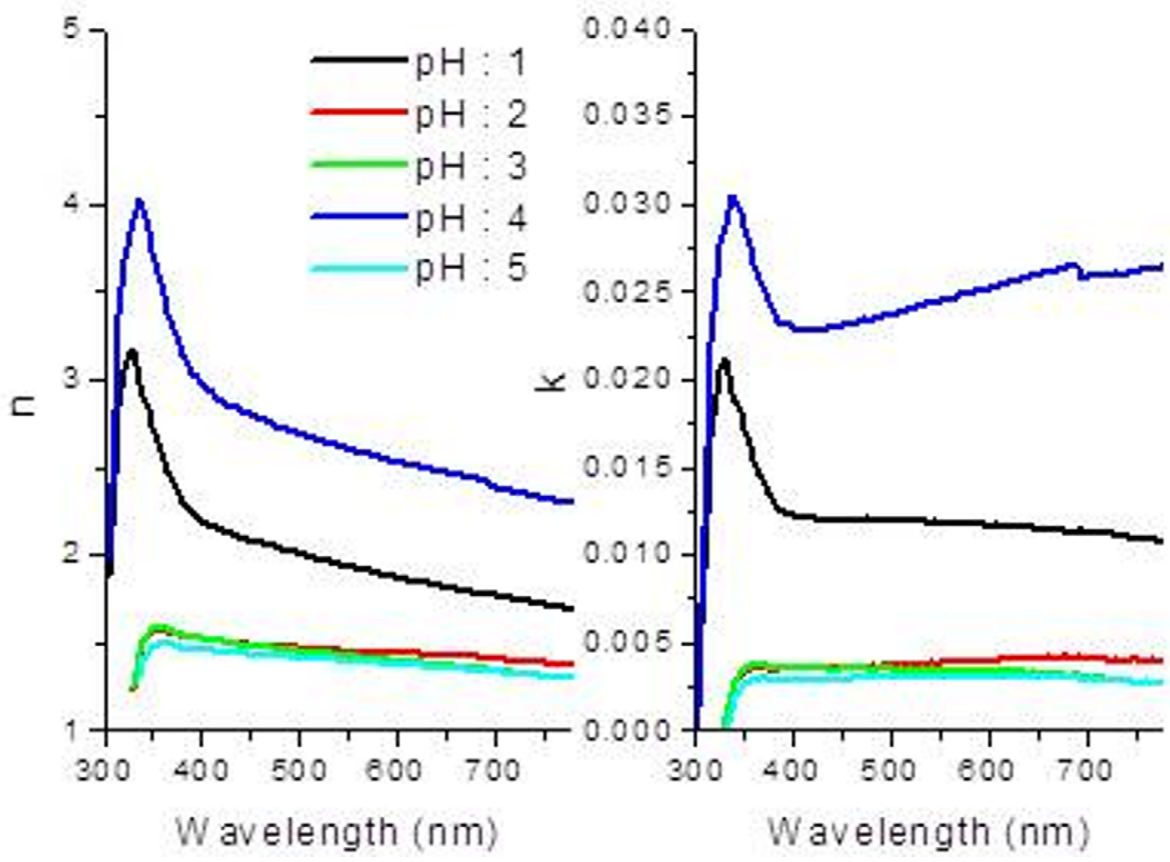

Figure 5. Refractive index (n) and extinction coefficient $(\mathrm{k})$ of $\mathrm{CeS}_{\mathrm{x}}$ thin films produced at different $\mathrm{pH}$.

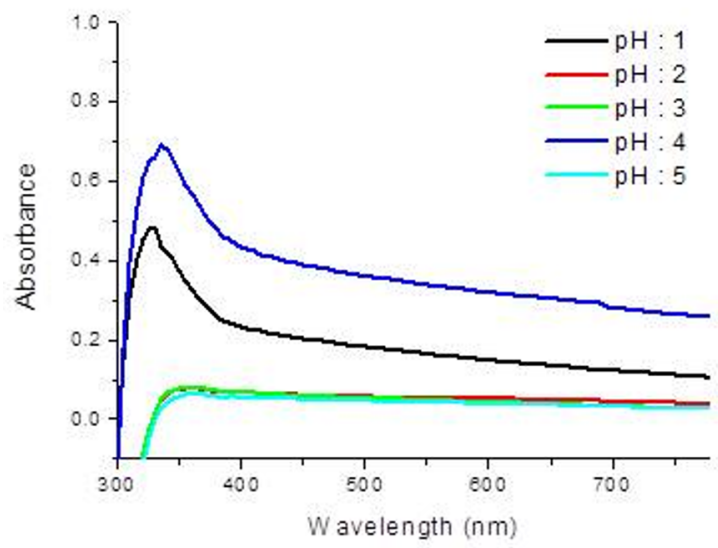

Figure 6. Absorbance of $\mathrm{CeS}_{\mathrm{x}}$ thin films produced at different $\mathrm{pH}$.

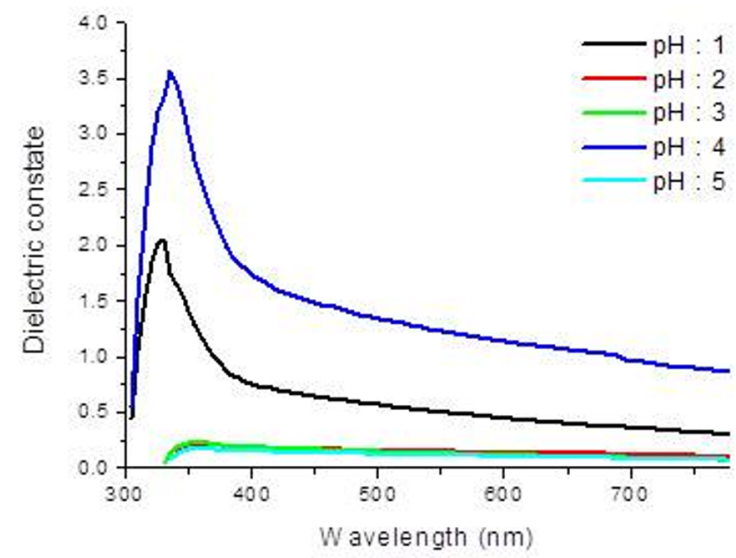

Figure 7. Dielectric constant of $\mathrm{CeS}_{\mathrm{x}}$ thin films produced at different $\mathrm{pH}$. start absorption over $450 \mathrm{~nm}$ wavelength. Therefore, an increase after that wavelength is observed on both reflective index and extinction coefficient and both increases parallel ${ }^{6}$. At the same time, reflective index may vary according to the thickness of the material. As the thickness of the film increases, the material absorbs more light, which leads to an increase on reflective index ${ }^{7}$.

Figure 6 and 7 show absorbance and dielectric constant of $\mathrm{CeS}_{\mathrm{x}}$ thin films produced at different $\mathrm{pH}$. The absorbance values of $0.164,0.053,0.048,0.338$ and 0.043 , are in line with the film thickness (at $550 \mathrm{~nm}$ wavelength). Dielectric constant values of $\mathrm{CeS}_{\mathrm{x}}$ are found as 0.501, 0.145, 0.131, 1.226 and 0.116 (at $550 \mathrm{~nm}$ wavelength). Higher absorbance and dielectric constant values are observed at 330-335-360 $\mathrm{nm}$ wavelength. Cerium sulfides are known as UV absorber material. Perrin and Wimmer have reported that doping alkali to the film has caused an electron transition between $4 \mathrm{f}-5 \mathrm{~d}$ orbitals. With the contribution of $3 p$ valance band of sulfide, a conduction band has been formed in UV region ${ }^{8}$. Therefore, the electric area formed in the UV region has considerably affected dielectric constant. Moreover, thick film contains more particle, which leads to an increase on the absorption and some increases may be observed on the dielectric constant ${ }^{9}$. According to the literature, such a material with these optical properties is quite useful in semi-conductor technology ${ }^{10}$. 


\section{Conclusion}

In our previous study, we have produced crystalline cerium sulfide thin films. This paper is concerned with amorphous cerium thin films and their optical properties. We compare amorphous and crystalline thin films in terms of prominent optical properties in table 1 .

Table 1. Compare of the some optical properties of the amorphous and crystalline thin films.

\begin{tabular}{lcccc}
\hline & $\mathrm{pH}$ & $\begin{array}{c}\text { Optical } \\
\text { Band Gap } \\
(\mathrm{eV})\end{array}$ & $\begin{array}{c}\text { Refractive } \\
\text { index }(550 \\
\mathrm{nm})\end{array}$ & $\begin{array}{c}\text { Absorbance } \\
(550 \mathrm{~nm})\end{array}$ \\
\hline & 1 & 3.16 & 1.93 & 0.164 \\
Amorphous & 2 & 2.08 & 1.45 & 0.0053 \\
structures & 3 & 2.18 & 1.42 & 0.048 \\
& 4 & 3.04 & 2.60 & 0.338 \\
& 5 & 2.12 & 1.39 & 0.043 \\
\hline $\begin{array}{l}\text { Crystalline and } \\
\text { polycrystalline }\end{array}$ & 7 & 2.99 & 2.79 & 0.388 \\
phases $^{5}$ & 6 & 2.86 & 2.92 & 0.422 \\
& 9 & 2.92 & 2.19 & 0.231 \\
& 10 & 3.23 & 1.63 & 0.093 \\
\hline
\end{tabular}

It is well-known that optical band gaps of the amorphous thin films are lower than crystalline ones. Selji et al. discuss this subject in their study ${ }^{11}$. Urbrach tails form a conductivity band over the valance bands. Excited electrons switch to upper bands with lower energy, thus refractive index and the absorbance of crystalline thin films are higher than those of the amorphous ones, assuming that film thickness and average grain size are same. Refractive index and absorbance of the films increase in thicker films, with the interaction of the light with more grains ${ }^{12-13}$. It should be noted that amorphous $\mathrm{CeS}$ thin film glasses are convenient for UV absorber and opto-electronic devices.

\section{References}

1. Othmer K, ed. Kirk-Othmer Encyclopedia of Chemical Technology. Volume 5. Hoboken: John Wiley \& Sons; 2010. p. 670-7.
2. Berte JN. Cerium Pigments. In: Smith HN, ed. High Performance Pigments. Darmstadt: Wiley-VCH; 2002. p. 27-40.

3. Flahaut J. Sulfides, selenides and tellurides. In: Gschneider KA, Eyring L, eds. Handbook on the Physics and Chemistry of Rare Earths. Non-Metallic Compounds-II. Volume 4. Chap 31. Amsterdam: North Holland; 1979. p. 1-13.

4. Kariper İA. Synthesis and characterization of cerium sulfide thin film. Progress in Natural Science: Materials International. 2014;24(6):663-670.

5. Witz C, Huguenin D, Lafait J, Dupont S, Theye ML. Comparative optical studies of $\mathrm{Ce}_{2} \mathrm{~S}_{3}$ and $\mathrm{Gd}_{2} \mathrm{~S}_{3}$ compounds. Journal of Applied Physics. 1996;79(4):2038.

6. Saez, R. \& Caro, P.A. Rare Earths, Editorial Complutense, Madrid, 1998, pp. 327-33.

7. Kariper IA. Pb-Ag/I Thin Film by Co-Precipitation Method. Iranian Journal of Science and Technology, Transactions A: Science. 2016;40(2):137-143.

8. Perrin MA, Wimmer E. Color of pure and alkali-doped cerium sulfide: A local-density-functional study. Physical Review B: Condensed Matter. 1996;54(4):2428-2435.

9. Yakuphanoglu F, Sekercia M, Balaban A. The effect of film thickness on the optical absorption edge and optical constants of the Cr(III) organic thin films. Optical Materials. 2005;27(8):13691372 .

10. Kariper IA. Synthesis and characterization $\mathrm{Bi}_{2} \mathrm{O}_{2} \mathrm{~S}$ thin film via chemical bath deposition at low $\mathrm{pH}$. Spectrochimica Acta. Part A-Molecular and Biomolecular Spectroscopy. 2016;163:102-107.

11. Selj JH, Mongstad T, Hauback BC, Karazhanov SZ. The dielectric functions and optical band gaps of thin films of amorphous and cubic crystalline $\mathrm{Mg}_{\sim 2} \mathrm{NiH}_{\sim 4}$. Thin Solid Films. 2012;520(22):6786-6792.

12. Kariper İA. Production of $\mathrm{HfO}_{2}$ thin films using different methods: chemical bath deposition, SILAR and sol-gel process. International Journal of Minerals, Metallurgy and Materials. 2014;21(8):832-838.

13. Kariper İA. What Is the Effect of Critical Surface Tension of $\mathrm{PbSO}_{3}$ Thin Film? Metallurgical and Materials Transactions A. 2014;45(10):4398-4404. 